\title{
Клиническая иммунология
}

(C) Коллектив авторов, 2021

Саркисян Н.С. ${ }^{1}$, Куличенко А.Н. ${ }^{1}$, Ковалевич Н.И. ${ }^{1}$, Санникова И.В. ${ }^{2}$, Махиня О.В. ${ }^{3}$

\section{Комплексная оценка цитокинового профиля, протеинограмм и белков острой фазы воспаления у пациентов с острым бруцеллезом}

\author{
Федеральное казенное учреждение здравоохранения «Ставропольский научно-исследовательский противо- \\ чумный институт» Федеральной службы по надзору в сфере защиты прав потребителей и благополучия чело- \\ века, 355035, г. Ставрополь, Российская Федерация \\ ${ }^{2}$ Частное учреждение «Центр образовательной и клинической гастроэнтерологии, гепатологии и панкреатоло- \\ гии», 355012, г. Ставрополь, Российская Федерация \\ 3 «Центр иммунопрофилактики и предупреждения инфекционных заболеваний» Федерального государствен- \\ ного бюджетного образовательного учреждения высшего образования «Ставропольский государственный \\ медицинский университет» Министерства здравоохранения Российской Федерации, 355017, г. Ставрополь, \\ Российская Федерация
}

\section{Резюме}

Введение. Патогенез бруцеллеза напрямую связан с индукцией провоспалительных цитокинов и активацией иммунного ответа по Th1-типу. Роль факторов воспаления при остром бруцеллезе остается неизученной.

Цель исследования - определение уровня провоспалительных цитокинов (ИЛ-1 $\beta$, ИЛ-6, ИЛ-8, ИЛ-12, ИЛ-18 и ИФН- $)$, белков острой фазы воспаления (неоптерина и липополисахарид-связывающего белка) и выявление особенностей фракционного состава белков сыворотки крови у пациентов с острым бруцеллезом до и после проведения комплексной антибактериальной терапии и приема иммуномодулятора Ликопида ${ }^{\circledR}$.

Материал и методы. Объект исследования - клинический материал (образцы крови) от 65 пациентов с лабораторно подтвержденным диагнозом «острый бруцеллез», поступивших в ГБУЗ СК «Городская клиническая больница № 2» г. Ставрополя. Концентрации цитокинов ИЛ-1 $\beta$, ИЛ-8, ИЛ-12, ИЛ-18, ИФН- $\gamma$ и острофазных белков определяли в сыворотке крови методом твердофазного иммуноферментного анализа, уровень ИЛ-6 иммунохемилюминесцентным методом, фракционный состав белков сыворотки крови с использованием электрофореза.

Результаты. В острую фазу бруцеллезной инфекции (до лечения) отмечается высокий уровень провоспалительных цитокинов (ИЛ-1 $\beta$, ИЛ-6, ИЛ-8, ИЛ-18 и ИФН- $\gamma$ ). После проведенного курса антибиотикотерапии (доксициклин и рифампициин, 6 нед) в сыворотке крови пациентов с бруцеллезом средней степени тяжести течения сохраняются высокие уровни ИЛ-8, ИЛ-18, свидетельствующие об активном воспалении. Уровни ЛПС-белка и неоптерина на фоне терапии статистически значимо снизились. Установлена диспротеинемия с повышением уровня глобулинов, в основном за счет $\alpha$ и $\gamma$-глобулиновых фракций, умеренным снижением концентрации общего белка, гипоальбуминемией, снижением альбумино-глобулинового коэффициента.

Заключение. Отмечена перспектива дальнейшего изучения цитокинового профиля (ИЛ-1 $\beta$, ИЛ-6, ИЛ-8, ИЛ-12, ИЛ-18, ИФН- $\gamma$ ) для оценки интенсивности системного ответа на инфекцию и прогноза течения острого бруцеллеза.

Ключевые слова: бруцеллез; протеинограмма; цитокины; белки острой фазы; Ликопид

Статья получена 04.04.2021. Принята в печать 17.08.2021.

Для цитирования: Саркисян Н.С., Куличенко А.Н., Ковалевич Н.И., Санникова И.В., Махиня О.В. Комплексная оценка цитокинового профиля, протеинограмм и белков острой фазы воспаления у пациентов с острым бруцеллезом. Иммунология. 2021; 42 (5): 511-517. DOI: https://doi.org/10.33029/0206-4952-2021-425-511-517

Финансирование. Исследование не имело спонсорской поддержки.
Для корреспонденции Саркисян Нушик Сааковна кандидат медицинских наук, заведующий отделом консультационнопрофилактической работы, врач клинической лабораторной диагностики ФКУЗ СтНИПЧИ Роспотребнадзора, Ставрополь,

Российская Федерация E-mail: nyshik25@yandex.ru https://orcid.org/0000-0003-3512-5738

Конфликт интересов. Авторы заявляют об отсутствии конфликта интересов. 
Sarkisyan N.S. ${ }^{1}$, Kulichenko A.N. ${ }^{1}$, Kovalevich N.I. ${ }^{1}$, Sannikova I.V.', Makhinya O.V. ${ }^{3}$

\section{Complex assessment of the cytokine profile, proteinograms and inflammation acute phase proteins in patients with acute brucellosis}

${ }^{1}$ Stavropol Plague Control Research Institute of the Federal Service for Surveillance in the Sphere of Consumers Rights Protection and Human Welfare, 355035, Stavropol, Russian Federation

${ }^{2}$ Center for Educational and Clinical Gastroenterology, Hepatology and Pancreatology, 355012, Stavropol, Russian Federation

${ }^{3}$ Center for immunoprophylaxis and prevention of infectious diseases of the Stavropol State Medical University of the Ministry of Health of Russian Federation, 355017, Stavropol, Russian Federation

\section{Abstract}

Introduction. The pathogenesis of brucellosis is directly related to the induction of proinflammatory cytokines and activation of the Th1-type immune response. The role of inflammatory factors in acute brucellosis remains unexplored.

Aim of the study - to determine the level of proinflammatory cytokines (IL-1 $\beta$, IL-6, IL-8, IL-12, IL-18 and IFN- $\gamma$ ), proteins of the acute phase of inflammation (neopterin and lipopolysaccharide-binding protein) and features of the fractional composition of blood serum proteins in patients with acute brucellosis before and after complex antibiotic therapy and taking an immunomodulator Licopid ${ }^{\circledR}$.

Material and methods. The object of the study were clinical blood samples from 65 patients with a laboratory-confirmed diagnosis of acute brucellosis, admitted to the State Medical Institution «City Clinical Hospital No. 2», Stavropol. The concentrations of cytokines (IL-1 $\beta$, IL-8, IL-12, IL-18, IFN- $\gamma$ ) and acute phase proteins were determined in blood serum by enzyme-linked immunosorbent assay, IL-6 level - by immunochemiluminescence method, fractional composition of blood serum proteins - using electrophoresis.

Results. In the acute phase of brucellosis infection (before treatment), there is a high level of pro-inflammatory cytokines IL-1 $\beta$, IL- 6 , IL-8, IL-18 and IFN- $\gamma$. After the course of antibiotic therapy (doxycycline and rifampicin, 6 weeks), high level of IL- 8 and IL-1 8 remains in the blood serum of patients with moderate brucellosis, indicating active inflammation. The level of LPS protein and neopterin decreased statistically significant during therapy. Dysproteinemia was shown with an increase in the level of globulins, mainly due to $\alpha$ - and $\gamma$-globulin fractions, a moderate decrease in the concentration of total protein, hypoalbuminemia, and a decrease in the albumin-globulin coefficient.

Conclusion. The prospect of further study of the cytokine profile (IL-1 $\beta$, IL-6, IL-8, IL-12, IL-18, INF- $\gamma$ ) to assess the intensity of the systemic response to infection and to predict the course of acute brucellosis is noted.

Keywords: brucellosis; proteinogram; cytokines; acute phase proteins; Licopid $^{\circledR}$

Received 04.04.2021. Accepted 17.08.2021.

For citation: Sarkisyan N.S., Kulichenko A.N., Kovalevich N.I., Sannikova I.V., Makhinya O.V. Complex assessment of the cytokine profile, proteinograms and inflammation acute phase proteins in patients with acute brucellosis. Immunologiya. 2021; 42 (5): 511-7. DOI: https://doi.org/10.33029/0206-4952-2021-42-5-511-517 (in Russian)

Funding. The study had no sponsor support.

Conflict of interests. The authors declare no conflict of interests.

\section{Введение}

Бруцеллез относится к бактериальным зоонозам; особенность его патогенеза заключается во внутриклеточном паразитировании возбудителя с незавершенным фагоцитозом, определяющим высокий риск трансформации в хроническое течение заболевания [1-6]. Известно, что при бруцеллезе ключевая роль принадлежит клеточному иммунитету и дисбалансу Th1-, про- и противовоспалительных цитокинов, а также интерферонов (ИФН), прежде всего ИФН- $\gamma$, необходимых для противодействия возбудителю $[7,8]$.

Цитокины выполняют регуляторную функцию, контролируют процессы воспаления, иммунного ответа на чужеродные антигены (отражают первичную реакцию на этиотропный агент). Исследование цитокинового статуса 
позволяет оценить характер течения процесса и прогнозировать исход заболевания при многих инфекциях, объективно оценить эффективность терапии. Определение динамики уровня про- и противовоспалительных цитокинов дает возможность характеризовать реакцию иммунной системы при конкретной инфекции [9].

Исследование белковых фракций сыворотки крови один из наиболее распространенных биохимических анализов, позволяющих получить более полную картину клинико-физиологического состояния организма. При многих заболеваниях наблюдается изменение соотношения белковых фракций (диспротеинемия) при нормальном содержании общего белка.

Важными компонентами врожденных механизмов резистентности к инфекции являются острофазовые белки - неоднородная группа белковых субстанций, которые интенсивно синтезируются при развитии острой фазы воспаления под влиянием цитокинов: интерлейкина(ИЛ)-6, ИЛ-1 $\beta$ и фактора некроза опухоли $\alpha$ $(\Phi Н О \alpha)$. Так, липополисахарид-связывающий белок (ЛПС-белок) синтезируется в клетках печени, легких и в энтероцитах под действием ИЛ-1, ИЛ-6 [7]. Этот белок обладает участком высокоаффинного связывания липополисахарида (ЛПС) грам-отрицательных бактерий. Образующийся комплекс ЛПС-белок/ЛПС взаимодействует с CD14 на поверхности макрофагов. В результате запускается каскад реакций, в конечном итоге приводящих к активации основных клеточных функций, связанных с развитием фагоцитоза и синтезом провоспалительных цитокинов ИЛ-12 и ИЛ-18 [6].

Одним их серологических маркеров активации Th1типа иммунного ответа является неоптерин, представляющий собой метаболит нуклеиновых оснований, по структуре схожий с молекулой фолиевой кислоты $[10,11]$. Основным индуктором его синтеза является ИФН- $\gamma$, при этом другие провоспалительные Тh1цитокины (ФНО $\alpha$ и ИЛ-2) резко усиливают выработку неоптерина, стимулированную ИФН- $\gamma$ [12]. Это дает основание рассматривать неоптерин в качестве интегрального показателя цитокин-зависимой активации моноцитов/макрофагов [4]. Неоптерин участвует в патогенезе многих заболеваний, связанных с активацией клеточного звена иммунитета. Увеличение его концентрации коррелирует с изменениями уровней ИНФ- $\gamma$ и ФНО $\alpha$ и приводит к системному воспалительному ответу. Установлено, что гиперпродукция неоптерина напрямую сопряжена с активаторным влиянием этих цитокинов на метаболизм иммунных клеток [10, 13]. Данный показатель играет роль в реализации механизма цитотоксического действия активированных макрофагов.

Патогены, персистирующие внутри клеток (риккетсии, хламидии, шигеллы, бруцеллы, микобактерии), в острую фазу индуцируют клеточно-опосредованный иммунный ответ, в последующем, на более поздних сроках инфекционного процесса, развиваются гуморальные иммунные реакции [14].

Изучение особенностей фракционного состава белков сыворотки крови, уровня неспецифических острофазовых показателей неоптерина и ЛПС-белка в корреляции с комплексом провоспалительных цитокинов (ИЛ-1 $\beta$, ИЛ-6, ИЛ-8, ИЛ-12, ИЛ-18) и ИНФ- $\gamma$ при остром бруцеллезе позволит расширить представления об иммунопатогенезе этой инфекции.

Цель исследования - проведение комплексной оценки цитокинового профиля (ИЛ-1 $\beta$, ИЛ-6, ИЛ-8, ИЛ-12, ИЛ-18 и ИФН- $\gamma$ ), белкового спектра и белков острой фазы воспаления (неоптерина и ЛПС-белка) у пациентов с острым бруцеллезом.

\section{Материал и методы}

Участники исследования. Исследовали образцы крови от 65 пациентов с лабораторно подтвержденным диагнозом «острый бруцеллез», поступивших в бруцеллезное отделение ГБУЗ СК «Городская клиническая больница № 2» г. Ставрополя. Все клинические исследования проводили после получения информированного добровольного согласия от обследуемых. Клинические исследования выполняли с соблюдением принципов Хельсинкской декларации; исследование одобрено экспертной комиссией ФКУЗ «Ставропольский противочумный институт» Роспотребнадзора (экспертное заключение № 48 от 08.04.2021) и ФГБОУ ВО «Ставропольский государственный медицинский университет» Минздрава России (экспертное заключение № 14 от 22.10.2020). Диагноз «бруцеллез» устанавливали на основании данных эпидемиологических, клинических и лабораторных исследований.

Согласно данным из выписок историй болезни, у всех пациентов бруцеллез характеризовался среднетяжелым течением. В большинстве случаев $(75,4$ \%) диагностированы очаговые проявления бруцеллезной инфекции в виде костно-суставных проявлений: реактивные артриты (56,9 \%), сакроилеит (16,9\%). У 16 (24,62 \%) пациентов определены только признаки генерализации инфекции без формирования очаговых поражений. Основные клинические проявления - лихорадка различной степени выраженности, артралгии, гепатоспленомегалия (89,2%). У большинства пациентов $(81,5 \%)$ температурная реакция достигала фебрильных значений (38-39 $\left.{ }^{\circ} \mathrm{C}\right)$, субфебрильная температура наблюдалась у 7 (10,8 \%) пациентов и только у 5 (7,7 \%) пациентов установлена пиретическая лихорадка $\left(>39^{\circ} \mathrm{C}\right)$.

Группу сравнения составили здоровые добровольцы $(n=32)$, не переболевшие бруцеллезом и не вакцинированные против этой инфекции. Группы были сопоставимы по полу и возрасту.

Лабораторные исследования. Обеззараживание исследуемого материала осуществляли в соответствии СП 1.3.3118-13 «Безопасность работы с микроорганизмами I-II групп патогенности (опасности)». Концентрацию общего белка определяли на биохимическом анализаторе Cobas с 311 (Roche diagnostics, Швейцария), фракционный состав белков сыворотки крови - с использованием системы для электрофореза (SAS-1 + SAS-2), HELENA (Великобритания), с применением тест-системы «Белки-сыворотки-24» (Helena 
BioSciences Europe, Великобритания). Методом твердофазного иммуноферментного анализа проведено определение уровней ИЛ-1 $\beta$, ИЛ-8, ИЛ-12, ИЛ-18, ИФН- $\gamma$ в сыворотке крови с использованием тест-систем «ИФА-ВЕКТОР-БЕСТ» (Вектор-Бест, Россия). Уровень ИЛ-6 определяли иммунохемилюминесцентным методом на анализаторе Cobas e 411 (Roche diagnostics, Швейцария). Определение уровня неоптерина выполняли с использованием тест-систем Neopterin ELISA («IBL, Hamburg», Германия). ЛПС-белок определяли с помощью тест-системы Hbt Human LBP ELISA (Hycult biotechnology, Голландия).

Исследование показателей проводили до и после курса антибиотикотерапии (доксициклин и рифампицин в течение 6 нед). Затем всем пациентам с острым бруцеллезом была назначена иммуномодулирующая терапия: Ликопид ${ }^{\circledR}$ в дозировке 10 мг курсом 21 день. Отсутствие высокоэффективных схем антибактериальной терапии, высокий риск формирования хронического течения бруцеллеза и особенности иммунопатогенеза заболевания (незавершенный фагоцитоз, внутриклеточное паразитирование) стали основанием для назначения курса иммунокорригирующей терапии в комплексном лечении бруцеллеза. Средства иммунотерапии и иммунокоррекции применяются при лечении бруцеллеза (Клинические рекомендации Министерства здравоохранения РФ «Бруцеллез у взрослых», утверждены 30.10.2014; п. 4.11).

Статистическая обработка. Для статистического анализа использовали $T$-критерий Вилкоксона и $t$-критерий Стьюдента для несвязанных совокупностей. Уровень достоверности принимали равным $p<0,05$.

\section{Результаты}

В ходе проведенного исследования установлено, что у пациентов с острым бруцеллезом до начала антибиотикотерапии уровень ИЛ-12 составил 25,66 \pm 0,72 пг/мл, что ниже $(p<0,05)$ показателя в группе сравнения $(31,75 \pm 0,72$ пг/мл). После антибиотикотерапии уровень ИЛ-12 не изменился $(25,87 \pm 0,89$ пг/мл; $p>0,05)$. Применение иммунотропного средства сопровождалось увеличением уровня ИЛ-12 в среднем до $38,13 \pm$ 2,34 пг/мл $(p<0,001)$. Ликопид ${ }^{\circledR}$ способствовал активации синтеза ИЛ-12, что положительно повлияло на формирование адаптивного иммунного ответа. В сыворотке крови пациентов с острым бруцеллезом уровень ИЛ-12, ключевого цитокина в инициации лимфоцит-зависимого иммунного ответа, был ниже, чем в контрольной группе $(p<0,05)$. Селективное ингибирование синтеза ИЛ-12 при сохранении продукции других провоспалительных цитокинов (ИЛ-8, ИФН- $\gamma$ ), вероятно, является одним из факторов длительной персистенции Brucella spp. в организме хозяина.

Уровень ИЛ-18 у пациентов с острым бруцеллезом до антибиотикотерапии значительно превысил $(p<0,05)$ показатель в группе сравнения $(32,37 \pm 0,63$ пг/мл) $68,5 \pm 12,5$ пг/мл, после завершения антибактериальной терапии уровень ИЛ-18 составил 66,4 \pm 10,9 пг/мл. При иммуномодуляторной терапии уровень ИЛ-18 прак- тически не изменился - 67,73 $\pm 11,48$ пг/мл. Несмотря на проведенный курс приема Ликопида ${ }^{\circledR}$ в сыворотке крови пациентов сохраняется высокий уровень ИЛ-18. Это может свидетельствовать об активном воспалении при отсутствии клинических проявлений болезни.

Уровень ИЛ-8 у пациентов с острым бруцеллезом до лечения составил $8,66 \pm 0,59$ пг/мл и значительно $(p<0,05)$ превысил соответствующий показатель в группе сравнения $(4,33 \pm 0,8$ пг/мл). После антибиотикотерапии уровень ИЛ-8 оставался высоким $(8,76 \pm 0,96$ пг/мл), не отличаясь от исходного $(p>0,05)$. Прием Ликопида ${ }^{\circledR}$ способствовал снижению (6,44 \pm 0,14 пг/мл) уровня ИЛ-8 - это связано с уменьшением воспалительного процесса на фоне терапии.

Уровень ИЛ-6 до лечения - 17,39 $\pm 1,3$ пг/мл $(p<0,05)$ превысил соответствующие значения в группе сравнения $(6,67 \pm 0,60$ пг/мл). Анализ данных показал, что у пациентов с острым бруцеллезом после лечения антибиотиками уровень ИЛ-6 составил 14,4 2,36 пг/мл, после приема иммуномодулятора данные были сопоставимы 14,1 \pm 1,42 пг/мл. Высокий уровень провоспалительного цитокина ИЛ-6 свидетельствует о стимуляции иммунного ответа и опосредует острую фазу воспаления. ИЛ-6 стимулирует пролиферацию и дифференцировку В- и Т-клеток.

В ходе проведенного исследования установлено, что до начала специфического лечения у пациентов с острым бруцеллезом уровень ИЛ- $1 \beta(8,35 \pm 0,47$ пг/мл) был значительно выше по сравнению со значением в группе сравнения $(1,6 \pm 0,39$ пг/мл; $p<0,05)$. Это связано с тем, что ИЛ-1 $\beta$ участвует в первичной стадии иммунного ответа: активирует лимфоциты (Т-хелперы) и способствует трансформации В-лимфоцитов в плазматические клетки, которые, в свою очередь, участвуют в образовании антител. После курса антибиотикотерапии уровень ИЛ- $1 \beta$ снизился до 5,98 \pm 0,62 пг/мл, прием Ликопида ${ }^{\circledR}$ способствовал снижению уровня ИЛ-1 $\beta$ $2,67 \pm 0,62$ пг/мл $(p<0,001)$.

Уровень ИФН- $\gamma$ в сыворотке крови пациентов с острым бруцеллезом до проведения антибиотикотерапии составил $18,22 \pm 5,03$ пг/мл $(p<0,05)$, что значительно превышало соответствующий показатель в группе сравнения (3,35 $\pm 0,6$ пг/мл). После завершения курса антибактериальной терапии уровень ИНФ- $\gamma$ снизился до 7,19 $\pm 3,03$ пг/мЛ $(p>0,05)$. Прием Ликопида ${ }^{\circledR}$ способствовал повышению уровня ИФН- $\gamma$ до 20,93 \pm 5,03 пг/мл $(p<0,05)$. Иммуномодулирующий эффект ИФН- $\gamma$ заключается в способности к регуляции взаимодействия клеток, участвующих в иммунном ответе, приводя к эффективной элиминации инфекционного агента.

Данные об уровне провоспалительных цитокинов и острофазовых белков представлены на рис. 1 .

Анализ уровня белков острой фазы воспаления показал, что у пациентов с острым бруцеллезом до лечения антибиотиками уровень ЛПС-белка составил 52,2 0,77 пг/мл $(p<0,05)$, что значительно выше по сравнению с группой сравнения $(6,98 \pm 0,76$ пг/мл; $p<0,05)$. 


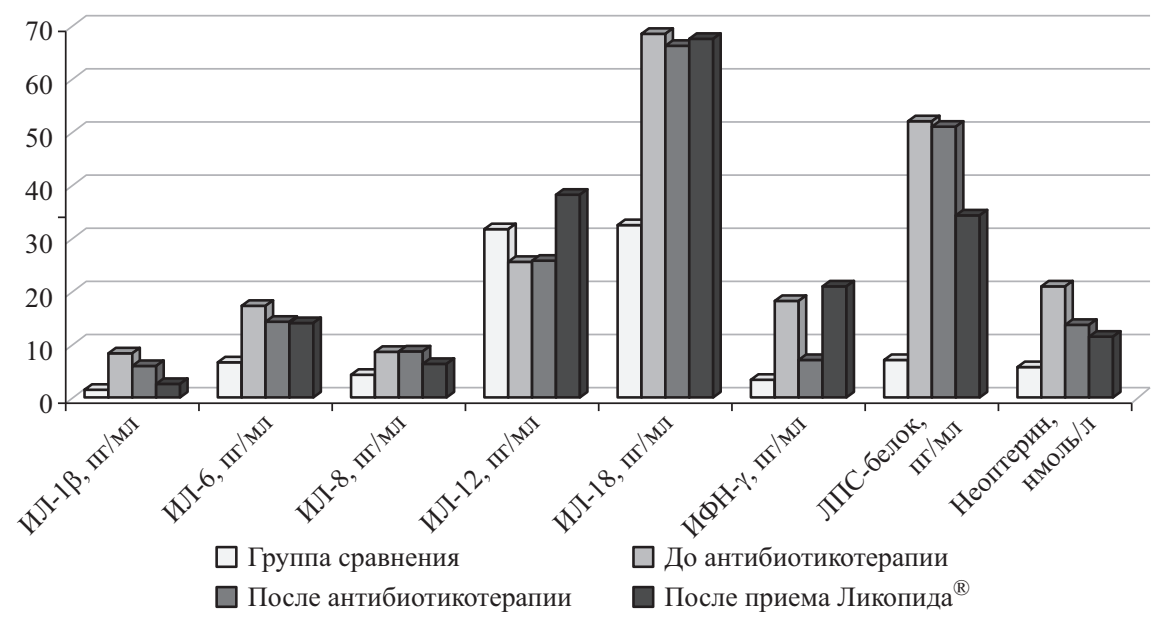

Рис. 1. Сравнительный анализ уровня провоспалительных цитокинов и острофазовых белков при остром бруцеллезе

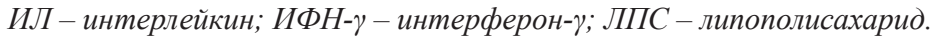

После курса антибиотикотерапии уровень ЛПС-белка составил 50,79 $\pm 0,78$ пг/мл, после курсового приема иммуномодулятора $-34,17 \pm 0,63$ пг/мл $(p<0,001)$.

Уровень неоптерина в сыворотке крови пациентов с бруцеллезом до начала специфической терапии составил $21,01 \pm 3,6$ нмоль/л, что значительно выше по отношению к группе сравнения $(5,7 \pm 0,54$ нмоль/л; $p<0,05)$. После окончания курса антибиотикотерапии уровень неоптерина снизился до $13,69 \pm 3,39$ нмоль/л $(p<0,05)$, но не достиг нормальных показателей. После курса приема Ликопида ${ }^{\circledR}$ уровень неоптерина снизился до $11,49 \pm 2,86$ нмоль/л, что меньше по сравнению с его уровнем до лечения $(p<0,05)$, но выше, чем в группе сравнения $(p<0,05)$.

У всех обследуемых также провели анализ концентрации общего белка, альбумина, $\alpha_{1}-$ и $\alpha_{2}$-фракций глобулинов, $\beta$ - и $\gamma$-глобулинов, а также рассчитали альбумин-глобулиновое соотношение (рис. 2).

Уровни $\alpha_{1}$ - и $\alpha_{2}$-фракции глобулинов в сыворотке крови пациентов составили 7,04 $\pm 0,23$ и 10,93 \pm $0,38 \%$ соответственно, что превышало показатели

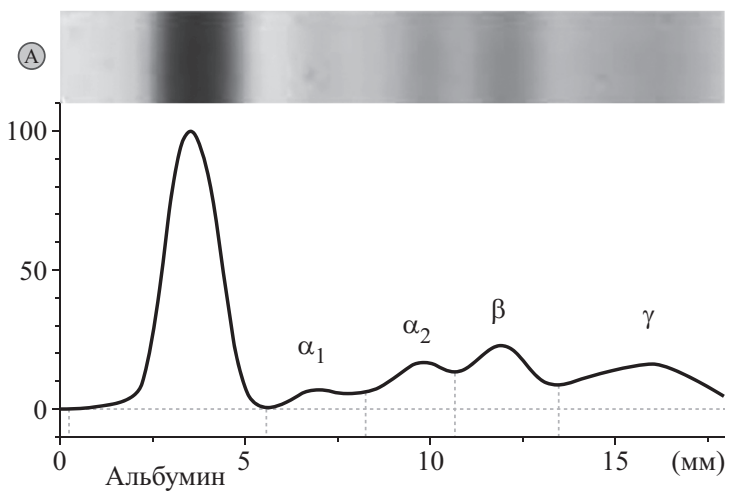

в группе сравнения $(4,3 \pm 0,24 \%$ и 9,73 $\pm 0,49 \%$, $p<0,05)$. Увеличение уровня $\alpha$-глобулинов при бруцеллезной инфекции можно связать с экссудативно-воспалительным процессом разной степени, вызывающим увеличение содержания в крови гаптоглобина, мигрирующего при электрофорезе вместе с $\alpha$-глобулинами. Наблюдалось также снижение концентрации общего белкадо 51,7 г/л (63,7-75,8 г/л), альбумина - до 39,7 г/л $(45,8-55,6$ г/л) и повышение относительного количества глобулинов - в среднем до 20,8 \% (11,7-28,6 \%), в основном за счет $\alpha$ - и $\gamma$-глобулиновых фракций. Количество $\beta$-глобулинов было в пределах нормы (8-15 \%). Повышение $\gamma$-глобулиновой фракции и появление М-пика в $\gamma$-зоне у пациентов с острым бруцеллезом связано с иммуновоспалительными реакциями, активацией антителогенеза и их концентрацией в сыворотке крови.

\section{Обссуждение}

В ходе проведенного исследования установлено, что в острую фазу бруцеллезной инфекции (до лече-

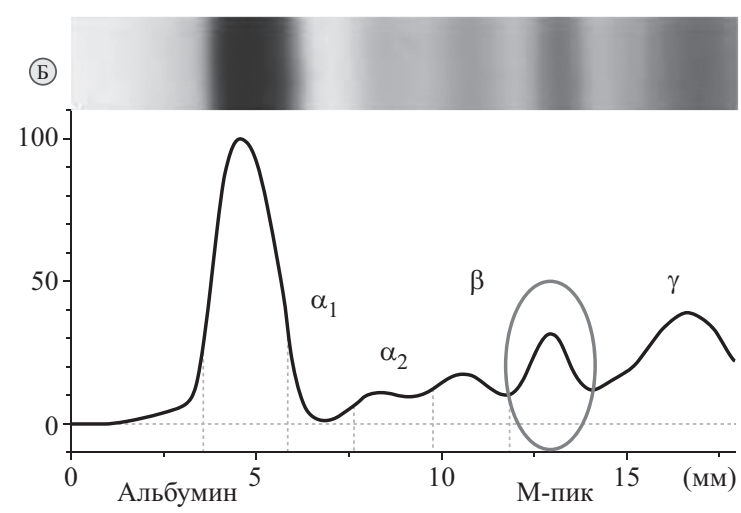

Рис. 2. Сравнительный анализ фракционного состава белков сыворотки крови: А - белковый профиль группы сравнения; Б - белковый профиль пациента с диагнозом «острый бруцеллез» 
ния) отмечается высокий уровень провоспалительных цитокинов (ИЛ-1 $\beta$, ИЛ-6, ИЛ-8, ИЛ-18 и ИФН- $\gamma)$. Они действуют на иммунокомпетентные клетки, инициируя воспалительный ответ. Ключевая роль в развитии воспалительных реакций, обусловленных системой клеточного иммунитета, против многочисленных внутриклеточных патогенов, в том числе бруцеллы, принадлежит ИФН- $\gamma$ [9], который продуцируется активированными Т-хелперами 1-го типа (Th1) и натуральными киллерами (НК-клетки). Высокий уровень ИФН- $\gamma$ в крови пациентов с острым бруцеллезом закономерно отражает активацию клеточного иммунного ответа [6].

После курса антибактериальной терапии в крови пациентов сохраняется высокий уровень ИФНс тенденцией к снижению, но он превышал показатели в группе сравнения. Полученные результаты свидетельствуют о сохраняющейся активности клеточного иммунного ответа, вероятно, о продукции клетками Th1и других провоспалительных цитокинов (ИЛ-1 $\beta$, ИЛ-6, ИЛ-8, ИЛ-18), стимулирующих цитотоксические клетки и Т-эффекторы гиперчувствительности замедленного типа. Несмотря на проведенный курс антибиотикотерапии у пациентов с острым бруцеллезом средней степенью тяжести течения продукция ИЛ-8, ИЛ-18 характеризовалась более высокими уровнями, свидетельствующими о воспалении. Продолжительный повышенный синтез цитокинов может стать фактором прогрессирования патологического процесса, оказывая прямое повреждающее действие на клетки и ткани, индуцируя альтерацию, нарушение целостности сосудистой стенки, усиление и хронизацию воспалительного процесса $[9,13]$.

У пациентов с бруцеллезом средней степени тяжести течения на фоне общей интоксикации (у 81,5 \% пациентов температура достигала фебрильных значений 38-39 ${ }^{\circ} \mathrm{C}$ ) усиливается также синтез белков острой фазы воспаления (ЛПС-белок, неоптерин), которые играют ключевую роль в патогенезе болезни.

Установленный нами высокий уровень ЛПС-белка подтверждает длительную персистенцию возбудителя несмотря на лечение антибиотиками и отсутствие полной эрадикации возбудителя. ЛПС бруцеллы выступает как иммуномодулирующий фактор, необходимый для выживания и репликации возбудителя в организме хозяина [6].

В крови пациентов с острым бруцеллезом установлен высокий уровень неоптерина, превышающий уровень в группе сравнения. Полученное значение уровня неоптерина в крови пациентов свидетельствуют об активных воспалительных реакциях на клеточном уровне $[8,11]$, индуктором которых является сохраняющаяся антигенная нагрузка. Повышенный уровень неоптерина имеет диагностическую значимость в оценке воспаления, степени тяжести течения заболевания и эффективности проводимой терапии $[5,8,11]$.

Результаты проведенных исследований также свидетельствуют о том, что при остром бруцеллезе наблюдается диспротеинемия: отмечается повышение в крови уровня глобулинов, в основном за счет $\alpha$ и $\gamma$-глобулиновых фракций, умеренное снижение концентрации общего белка в крови, гипоальбуминемия, снижение альбумино-глобулинового коэффициента.

Таким образом, в противодействии бруцеллезу ключевая роль принадлежит клеточному иммунитету и дисбалансу Th1-, про- и противовоспалительных цитокинов, а также интерферонов, прежде всего ИФН- $\gamma$, необходимых для элиминации возбудителя. ИФН- $\gamma$, неоптерин и ЛПС-белок относятся к иммуномодулирующим факторам реакции иммунитета на возбудителя.

Исход естественного течения бруцеллеза у человека определяется результатом иммунных реакций между бруцеллой и иммунной системой в виде полной эрадикации патогена или развитием внутриклеточного паразитизма с формированием хронического заболевания.

\section{Заключение}

Комплексная оценка цитокинового статуса (ИЛ-1 $\beta$, ИЛ-6, ИЛ-8, ИЛ-18, ИНФ- $\gamma$ ) и белков острой фазы воспаления (неоптерина и ЛПС-белка) отражает интенсивность локального и/или системного ответа на инфекцию. Патофизиологические изменения белкового состава сыворотки крови у пациентов с острым бруцеллезом характеризуются метаболической перестройкой, демонстрируя преимущественно воспалительный характер протеинограммы.

Выявление существующих взаимосвязей между многочисленными проявлениями заболевания и лежащими в их основе индивидуальными физиологическими и патологическими реакциями организма на данную инфекцию позволят определить объективные критерии активности бруцеллезного процесса. Выраженность и глубина патологических сдвигов в цитокиновом статусе, маркерах острой фазы воспаления при бруцеллезной инфекции отражают патогенетические механизмы формирования органных поражений при бруцеллезе и коррелируют с активностью инфекционного процесса.

Вклад авторов. Концепция и дизайн исследования Куличенко А.Н., Санникова И.В., Махиня О.В.; сбор и обработка материала - Саркисян Н.С., Ковалевич Н.И.; статистическая обработка - Саркисян Н.С., Махиня О.В.; написание текста - Саркисян Н.С., Ковалевич Н.И., Санникова И.В., Махиня О.В.; редактирование - Куличенко А.Н.

\section{- Литература}

1. Boschiroli M.L., Foulongne V., Callaghan D.O. Brucellosis: a worldwide zoonosis. Curr. Opin. Microbiol. 2001; 4: 58-64. DOI: https://doi.org/10.1016/s13695274(00)00165-x

2. Liautard J. P., Gross A., Dornand J. Interactions between professional phagocytes and Brucella spp. Microbiologia. 1996; 12 (2): 197-206. URL: https://
www.semanticscholar.org/paper/Interactions-between-professional-phagocytes-andLiautard-Gross/d049bb02c9ded49df92ba190bba250b63f55ae35

3. Жумадилова 3.К., Байсугуров Ж.Б. Ферментные системы фагоцитирующих моно-нуклеаров при различных вариантах течения бруцеллеза. Здравоохранение Казахстана. 1989; 6: 29-31. 
4. Mantur B.G., Amarnath S.K., Shinde R.S. Review of clinical and laboratory features of human brucellosis. J. Indian Med. Microbiol. 2007; 25 (3): 188-202. DOI https://doi.org/10.4103/0255-0857.34758

5. Васильева Е.В., Лапин С.В., Блинова Т.В. Сравнительная ценность квантиферонового теста, неоптерина и специфических противотуберкулезных антител для клинической лабораторной диагностики туберкулеза легких. Клиническая лабораторная диагностика. 2013; 5: 21-6. URL: https://cyberleninka.ru/ article/n/sravnitelnaya-tsennost-kvantiferonovogo-testa-neopterina-i-spetsificheskihprotivotuberkuleznyh-antitel-dlya-kliniko-laboratornoy

6. Санникова И.В., Махиня О.В., Малеев В.В., Дейнека Д.А., Голубь О.Г, Ковальчук И.В., Лямкин Г.И. Бруцеллез в Ставропольском крае: результать 15-летнего наблюдения эпидемиологических и клинических особенностей Терапевтический архив. 2015; 78 (11): 11-7. DOI: https://doi.org/10.17116/ terarkh2015871111-17

7. Ariza J., Corredoira J., Pallares R., Viladrich P. F., Rufi G., Pujol M., Gudiol F. Characteristics of and risk factors for relapse of brucellosis in humans. Clin. Infect. Dis. 1995; 20: 1241-9. DOI: https://doi.org/10.1093/clinids/20.5.1241

8. Гладких Р.А. Молочный В.П., Полеско И.В. Неоптерин как современный маркер воспаления. Детские инфекции. 2016; 5 (2): 19-23. DOI: https://doi. org/10.22627/2072-8107-2016-15-2-19-23

\section{- References}

1. Boschiroli M.L., Foulongne V., Callaghan D.O. Brucellosis: a worldwide zoonosis. Curr. Opin. Microbiol. 2001; 4: 58-64. DOI: https://doi.org/10.1016/s13695274(00)00165-x

2. Liautard J. P., Gross A., Dornand J. Interactions between professional phagocytes and Brucella spp. Microbiologia. 1996; 12 (2): 197-206. URL: https:// www.semanticscholar.org/paper/Interactions-between-professional-phagocytes-andLiautard-Gross/d049bb02c9ded49df92ba190bba250b63f55ae35

3. Zhumadilova Z. K. Baysugurov Zh. B. Enzyme systems of phagocytic mononuclears in various variants of the course of brucellosis. Healthcare of Kazakhstan 1989; 6: 29-31. (in Russian).

4. Mantur B.G., Amarnath S.K., Shinde R.S. Review of clinical and laboratory features of human brucellosis. J. Indian Med. Microbiol. 2007; 25 (3): 188-202. DOI: https://doi.org/10.4103/0255-0857.34758

5. Vasil'eva E.V., Lapin S.V., Blinova T.V. Comparative value of the quantiferon test, neopterin and specific anti-tuberculosis antibodies for clinical laboratory diagnosi of pulmonary tuberculosis. Clinical laboratory diagnostics. 2013; 5: 21-6. URL: https:// cyberleninka.ru/article/n/sravnitelnaya-tsennost-kvantiferonovogo-testa-neopterinai-spetsificheskih-protivotuberkuleznyh-antitel-dlya-kliniko-laboratornoy (in Russian)

6. Sannikova I.V., Makhinya O.V., Maleev V.V., Deyneka D.A., Golub O.G., Koval'chuk I.V., Lyamkin G.I. Brucellosis in the Stavropol Territory: results of 15 year observation of epidemiological and clinical features. Therapeutic Archive. 2015 78 (11): 11-7. DOI: https://doi.org/10.17116/terarkh2015871111-17 (in Russian)

7. Ariza J., Corredoira J., Pallares R., Viladrich P. F., Rufi G., Pujol M., Gudio F. Characteristics of and risk factors for relapse of brucellosis in humans. Clin. Infect. Dis. 1995; 20: 1241-9. DOI: https://doi.org/10.1093/clinids/20.5.1241

\section{Сведения об авторах}

Саркисян Нушик Сааковна - канд. мед. наук, зав. отд. консультационно-профилактической работы, врач клинической лаб. диагностики ФКУЗ «СтНИПЧИ Роспотребнадзора, Ставрополь, Российская Федерация

E-mail: nyshik25@yandex.ru

https://orcid.org/0000-0003-3512-5738

Куличенко Александр Николаевич - член-корр. РАН, д-р мед. наук, проф., директор ФКУЗ «СтНИПЧИ» Роспотребнадзора, Ставрополь, Российская Федерация

E-mail: kulichenko_an@list.ru

http://orcid.org/0000-0002-9362-3949

Ковалевич Надежда Игоревна - канд. мед. наук, зав. научно-профилактической клинико-диагностической лаб., врач клинической лаб. диагностики ФКУЗ «СтНИПЧИ» Роспотребнадзора, Ставрополь, Российская Федерация

E-mail: n.kovalevich@list.ru

http://orcid.org/0000-0002-3695-125X

Санникова Ирина Викторовна - д-р мед. наук, проф., частное учреждение «Центр образовательной и клинической гастроэнтерологии, гепатологии и панкреатологии», Ставрополь, Российская Федерация

E-mail:dr.sannikova@gmail.com

http://orcid.org/0000-0002-2840-1848

Махиня Ольга Васильевна - врач-инфекционист Центра иммунопрофилактики и предупреждения инфекционных заболеваний ФГБОУ ВО СтГМУ Минздрава России, Ставрополь, Российская Федерация

E-mail: olgapoltavskaya@yandex.ru
9. Смирнов И.Е., Митюшин И.Л., Кучеренко А.Г. Бакрадзе М.Д. Цитокиновый профиль при бактериальной и вирусной инфекции. Российский педиатрический журнал. 2014; 4: 14-9. URL: http://cyberleninka.ru/article/n/tsitokinovyyprofil-pri-bakterialnoy-i-virusnoy-infektsii-u-detey

10. Skendros P., Pappas G., Boura P. Cell-mediated immunity in human brucellosis. J Microbes Infect. 2011; 13 (2): 134-42. DOI: https://doi.org/10.1016/j. micinf.2010.10.015

11. Свиридов Е.А., Телегина Т.А. Неоптерин и его восстановленные формы: биологическая роль и участие в клеточном иммунитете. Успехи биологической химии. 2005; 45: 355-90. URL: https://www.fbras.ru/wp-content/uploads/2017/10/ sviridov

12. Ляпина Е.П., Шульдяков А.А., Спирина В.Ф. Хронический бруцеллез: этиология, патогенез, клиника, лечение. Саратов : Тактик-Студио, 2011: 160 с ISBN: 978-5-916-032-4.

13. Ющук Н.Д., Венгеров Ю.Я. Инфекционные болезни : национальное руководство. Москва : ГЭОТАР-Медиа, 2019: 848 с. ISBN: 978-5-9704-4817-5.

14. Лямкин Г.И., Пономаренко Д.Г., Худолеев А.А., Русанова Д.В., Вилинская С.В., Куличенко А.Н. Обзор эпидемиологической ситуации по бруцеллезу в Российской Федерации в 2015 г. и прогноз на 2016 г. Проблемы особо опасных инфекций. 2016; (2): 11-3. DOI: https://doi.org/10.21055/0370-1069-2016-2-11-13

8. Gladkikh R.A., Molochny V.P., Polesco I. V. Neopterin as a modern marke of inflammation. Children's infections. 2016; 5 (2): 19-23. DOI: https://doi. org/10.22627/2072-8107-2016-15-2-19-23 (in Russian)

9. Smirnov I.E., Mityushin I.L., Kucherenko A.G., Bakradze M. D. Cytokine profile in bacterial and viral infection. Russian Pediatric Journal. 2014; 4: 14-9. URL: http://cyberleninka.ru/article/n/tsitokinovyy-profil-pri-bakterialnoy-i-virusnoyinfektsii-u-detey (in Russian)

10. Skendros P., Pappas G., Boura P. Cell-mediated immunity in human brucellosis. J Microbes Infect. 2011; 13 (2): 134-42. DOI: https://doi.org/10.1016/j. micinf.2010.10.015

11. Sviridov E. A., Telegina T. A. Neopterin and its reduced forms: biological role and participation in cellular immunity. Advances in biological chemistry. 2005; 45: 355-90. URL: https://www.fbras.ru/wp-content/uploads/2017/10/sviridov (in Russian)

12. Lyapina E.P., Shul'dyakov A.A., Spirina V.F. Chronic brucellosis: etiology, pathogenesis, clinic, treatment. Saratov: Tactik-Studio, 2011: 160 p. ISBN: 978-5916-032-4. (in Russian)

13. Yushchuk N.D., Vengerov Yu.Ya. Communicable diseases: national guidelines. Moscow: GEOTAR-Media, 2019: 848 p. ISBN: 978-5-9704-4817-5. (in Russian)

14. Lyamkin G.I., Ponomarenko D.G., Khudoleev A.A., Rusanova D.V., Vilinskaya S.V., Kulichenko A.N. Review of the epidemiological situation of brucellosis in the Russian Federation in 2015 and forecast for 2016. Problems of particularly dangerous infections. 2016; (2): 11-3. DOI: https://doi.org/10.21055/0370 1069-2016-2-11-13 (in Russian)

\section{Authors' information}

Nushik S. Sarkisyan - PhD, Head of the Department of Consulting and Preventive Work, Clinical Lab. Diagnostics Physician, «StPCRI», Rospotrebnadzor, Stavropol, Russian Federation

E-mail: nyshik25@yandex.ru

https://orcid.org/0000-0003-3512-5738

Alexander N. Kulichenko - Corresponding Member of RAS, MD, PhD, Prof., Director of «StPCRI», Rospotrebnadzor, Stavropol, Russian Federation E-mail: kulichenko_an@list.ru

http://orcid.org/0000-0002-9362-3949

Nadezhda I. Kovalevich - PhD, Head of the Scientific and Preventive Clinical and Diagnostic Lab., Clinical Lab. Diagnostics Physician, «StPCRI», Rospotrebnadzor, Stavropol, Russian Federation

E-mail: n.kovalevich@list.ru

http://orcid.org/0000-0002-3695-125X

Irina V. Sannikova - MD, PhD, Prof., Center for Educational and Clinical Gastroenterology, Hepatology and Pancreatology, Stavropol, Russian Federation E-mail: dr.sannikova@gmail.com

http://orcid.org/0000-0002-2840-1848

Olga V. Makhinya - Center for Immunoprophylaxis and Prevention of Infectious Diseases, «StSMU» of the MOH of Russia, Stavropol, Russian Federation

E-mail: olgapoltavskaya@yandex.ru 